\title{
OPEN High voltage generation from wastewater by microbial fuel cells equipped with a newly designed low voltage booster multiplier (LVBM)
}

\author{
N’Dah Joel Koffi \& Satoshi Okabe ${ }^{\bowtie}$
}

\begin{abstract}
Although microbial fuel cells (MFCs) can produce renewable energy from wastewater, the generated power is practically unusable. To extract usable power from an MFC fed with wastewater, we newly developed a low voltage booster multiplier (LVBM), which is composed of a self-oscillating LVB and multistage voltage multiplier circuits (VMCs). The low output MFC voltage (ca. $0.4 \mathrm{~V}$ ) was successfully boosted up to $99 \pm 2 \mathrm{~V}$, which was the highest voltage that has been ever reported, without voltage reversal by connecting an LVB with 20 -stage VMCs. Moreover, the boosted voltage $(81 \pm 1 \mathrm{~V})$ was stably maintained for $>\mathbf{4 0} \mathrm{h}$ even after disconnecting the LVBM from the MFC. The energy harvesting efficiency of LVBM was $>80 \%$ when an LVB with 4-stage VMCs was charged to $9.3 \mathrm{~V}$. These results clearly suggest that the proposed LVBM system is an efficient and self-starting energy harvester and storage for low-power generating MFCs.
\end{abstract}

Microbial fuel cells (MFCs) are bio-electrochemical devices that can directly convert chemical energy in biodegradable organic matter to electrical energy by exoelectrogenic bacteria as catalyst. In MFCs, exoelectrogenic bacteria extract electrons from the energy source (simply oxidation) and transfer them to the anode through diverse extracellular electron transfer (EET) mechanisms (so-called anodic respiration). The resulting electrons are then transported to the cathode and used for the reduction reaction of oxidized compounds (i.e., oxygen in the case of air-cathode MFC), which generates electrical power ${ }^{1}$. If wastewater is used as an energy source, simultaneous wastewater treatment and renewable energy production can be achieved. Therefore, it is expected that MFC technology is a promising energy-positive wastewater treatment process. However, the power generated from individual MFCs is practically unusable (unable to directly drive even low-power electronic devices such as LEDs and wireless sensor radios) due to its high internal resistance and low voltage output, which is a current major issue of MFC technology. The required operating voltage of such devices ranges from 2 to $5 \mathrm{~V}$ at least, and the power consumption could be up to the order of $1 \mathrm{~W}^{2}$. The maximum theoretical voltage across anode and cathode $\left(E_{\text {cathode }}^{0}-E_{\text {bioanode }}^{0}\right.$ ) of a single air-cathode MFC is $1.14 \mathrm{~V}$ (assuming $E_{\text {bioanode }}^{0}=E_{\mathrm{NADH}}^{0}=-0.32 \mathrm{~V}$ and $E_{\text {cathode }}^{0}=E_{\text {oxygen }}^{0}=+0.82 \mathrm{~V}$ vs. SHE at neutral $\mathrm{pH}$, respectively) ${ }^{3}$. However, a typical observed open-circuit voltage $(\mathrm{OCV})$ of an air-cathode MFC is in a range of $0.2-0.5 \mathrm{~V}$ due to the losses of electrode potential, such as activation polarization, concentration polarization, and $\mathrm{Ohmic} \operatorname{losses}^{4}$, which are also dependent on substrate, microorganisms, electrode overpotentials, internal resistance and applied external resistance ${ }^{5,6}$. The power density that an MFC can typically generate is from 1 to $2000 \mathrm{~mW} \mathrm{~m}^{-24}$. Therefore, the MFC output voltage and power must be increased for practical uses.

So far, several MFCs were simply connected in series or in parallel to overcome the low voltage or power issue. However, although a serially stacked MFCs unit could provide a higher voltage, it has often been proven to be difficult and ineffective due to voltage reversal (reverse polarity owing to fuel shortage) of individual MFC units, leading to a significant overall voltage decay ${ }^{2,5-7}$. Recently, significant efforts have been made to control and suppress the voltage reversal occurrence by connecting individual MFC units with a maximum power point tracking (MPPT) system to charge a stacked polarized capacitor ${ }^{8,9}$. However, this technical approach could increase stacked voltages only within the range of 2 to $3 \mathrm{~V}^{8,9}$. 


\begin{tabular}{|c|c|c|c|c|c|c|}
\hline PMS & MFC reactor Type & MFC working voltage & MFC-stacked configuration & Output boosted voltage & Efficiency (\%) & Refs \\
\hline DC-DC voltage booster circuit & Two-chamber MFCs (1.2 mL) & $0.2-0.4 \mathrm{~V}$ & 3 MFCs unit in parallel & $>3 \mathrm{~V}$ & N/A & 20 \\
\hline $\begin{array}{l}\text { Blocking oscillator booster } \\
\text { circuit }\end{array}$ & Two-chamber MFCs $(120 \mathrm{~mL})$ & $0.837 \mathrm{~V}$ & 3 MFCs unit in series & $\sim 3 \mathrm{~V}$ & N/A & 10 \\
\hline $\begin{array}{l}\text { DC-DC voltage Boost } \\
\text { converter }\end{array}$ & Two-chamber MFCs (50 mL) & $<0.2 \mathrm{~V}$ & Single or 4 parallel MFCs unit & $3.3 \mathrm{~V}$ & N/A & 6 \\
\hline $\begin{array}{l}\text { Capacitor-based DC-DC } \\
\text { converter }\end{array}$ & Air-cathode MFC (27 mL) & $\sim 0.5 \mathrm{~V}$ & 4 parallel MFCs unit & $2.5 \mathrm{~V}$ & N/A & 7 \\
\hline $\begin{array}{l}\text { Capacitor-based DC-DC } \\
\text { converter }\end{array}$ & $\begin{array}{l}\text { Sediment Microbial Fuel Cells } \\
\text { ( } 550 \mathrm{~mL} \text { anolyte, } 445 \mathrm{~mL} \\
\text { catholyte) }\end{array}$ & $0.4 \mathrm{~V}$ & Single MFC unit & $3.3 \mathrm{~V}$ & N/A & 11 \\
\hline $\begin{array}{l}\text { Synchronous Flyback con- } \\
\text { verter }\end{array}$ & Two-chamber MFCs $(150 \mathrm{~mL})$ & $0.310 \mathrm{~V}$ & Single MFC unit & $2.13 \mathrm{~V}$ & 50.3 & 12 \\
\hline Diode-based Boost-converter & Two-chamber MFCs $(150 \mathrm{~mL})$ & $0.311 \mathrm{~V}$ & Single MFC unit & $1.83 \mathrm{~V}$ & 22 & 12 \\
\hline $\begin{array}{l}\text { DC-DC voltage Boost con- } \\
\text { verter + supercapacitor }\end{array}$ & $\begin{array}{l}\text { Single-chamber air-cathode } \\
\text { MFC }(316 \mathrm{~mL})\end{array}$ & $0.3 \mathrm{~V}$ & Single MFC unit & $3.3 \mathrm{~V}$ & 5.33 & 2 \\
\hline Flyback converters & Benthic MFC & $0.35-0.5 \mathrm{~V}$ & Large scale benthic MFC & $12 \mathrm{~V}$ & 77 & 13 \\
\hline Flyback converters & Air-cathode MFC (450 mL) & $0.44 \mathrm{~V}$ & Single MFC unit & $5 \mathrm{~V}$ & 26 & 14 \\
\hline $\begin{array}{l}\text { Transformer-based } \\
\text { booster + supercapacitor }\end{array}$ & $\begin{array}{l}\text { Single-chamber air-cathode } \\
\text { MFC }(316 \mathrm{~mL})\end{array}$ & $0.18 \mathrm{~V}$ & Single MFC unit & $3.3 \mathrm{~V}$ & N/A & 22 \\
\hline LVB & $\begin{array}{l}\text { Single-chamber air-cathode } \\
\text { MFC }(300 \mathrm{~mL})\end{array}$ & $0.2-0.5 \mathrm{~V}$ & Single MFC unit & $5.2 \mathrm{~V}$ & N/A & 16 \\
\hline $\begin{array}{l}\text { UPEM boost converter with } \\
\text { one storage capacitor and } \\
\text { switch IC }\end{array}$ & Sediment MFC (15 L) & $0.2 \mathrm{~V}$ & Single MFC unit & $3.3 \mathrm{~V}$ & $28-36.5$ & 15 \\
\hline LVBM-[4] & $\begin{array}{l}\text { Single-chamber air-cathode } \\
\text { MFC }(300 \mathrm{~mL})\end{array}$ & $0.2-0.5 \mathrm{~V}$ & Single MFC unit & $17 \mathrm{~V}$ & $82-83$ & This study \\
\hline LVBM-[8] & $\begin{array}{l}\text { Single-chamber air-cathode } \\
\text { MFC }(300 \mathrm{~mL})\end{array}$ & $0.2-0.5 \mathrm{~V}$ & Single MFC unit & $35 \mathrm{~V}$ & N/A & This study \\
\hline LVBM-[20] & $\begin{array}{l}\text { Single-chamber air-cathode } \\
\text { MFC }(300 \mathrm{~mL})\end{array}$ & $0.2-0.5 \mathrm{~V}$ & Single MFC unit & $99 \mathrm{~V}$ & N/A & This study \\
\hline
\end{tabular}

Table 1. Comparison of previously reported MFC equipped with commercially available or individually developed power management systems (PMSs). UPEM: Ultra-low power energy for MFC; IC: Integrated circuit; LVBM-[n]: Low voltage booster multiplier with the cascade multiplier stage number [n]. N/A: Not available.

Alternatively, power management systems (PMSs) have been proposed to boost the low MFC output voltage to a certain required voltage and store enough energy to power the electronic loads. The PMSs basically utilize a combination of a direct current to direct current (DC/DC) converter to boost low MFC voltage to usable levels and a supercapacitor to store electrical energy temporarily. To date, various types of commercially available or individually developed PMSs were proposed to interface MFCs with electronic loads, and their performances were evaluated ${ }^{2,6,7,10-16}$ (Table 1 ). We have also successfully achieved a boosted voltage of $5.2 \mathrm{~V}$ from wastewater by a single-chamber air-cathode MFC equipped with a low voltage booster (LVB) ${ }^{16}$. Two units of an MFC equipped with an individual commercially available PMS were connected in series, which could generate only a final stacked voltage of $6.6 \mathrm{~V}^{6}$. In these studies, low MFC output voltages were increased to 2-12 V, which could drive only low voltage electronic devices but still not enough for real-world applications. Most of the existing PMSs for MFC applications are manufactured to only boost the low voltage, not further amplify or multiply the boosted voltage. Accordingly, to further increase the output voltage, a secondary voltage multiplier or amplifier of the primary boosted voltage is required.

In this study, we therefore propose a new two-step "boost-and-multiply" system, in which the low MFC output voltage is firstly boosted into an alternating current $(\mathrm{AC})$ voltage by a transistor-based self-oscillating low voltage booster circuit $^{16}$. After, the boosted $\mathrm{AC}$ voltage is further multiplied and turned back into a direct current (DC) voltage by a multistage Single-Phase Cockroft-Walton voltage multiplier circuit (VMC) ${ }^{17,18}$. We have manufactured a low voltage booster multiplier (LVBM) and tested its performance using a single-chamber air-cathode MFC treating domestic wastewater as a power source. A low voltage booster with a 20 -stage alternating current to direct current (AC/DC) voltage multiplier circuit was able to amplify the MFC voltage (ca. $0.4 \mathrm{~V}$ ) up to $99 \pm 2 \mathrm{~V}$ and retain for a few days without voltage reversal, which was the highest boosted voltage that has ever been reported. The feasibility of LVBM application in MFC technology is discussed.

\section{Materials and methods}

Air-cathode MFC setup and operation. A single-chamber air-cathode MFC was made from an acrylic block $\left(20 \times 18 \times 3 \mathrm{~cm}^{3}\right)$ and composed of the serpentine flow field with a working volume of $0.3 \mathrm{~L}$. The MFC system consists of 4 anode graphite fiber brushes [ $2.2 \mathrm{~cm}$ (diameter) $\times 12 \mathrm{~cm}$ (length), Mill-Rose, Mentor, OH] installed in 4 flow channels, which are sandwiched with 2 separator electrode assembly (SEA) cells as previously described ${ }^{16}$. MFC had two-sided polyvinylidene fluoride (PVDF)-based activated carbon air-cathodes. 


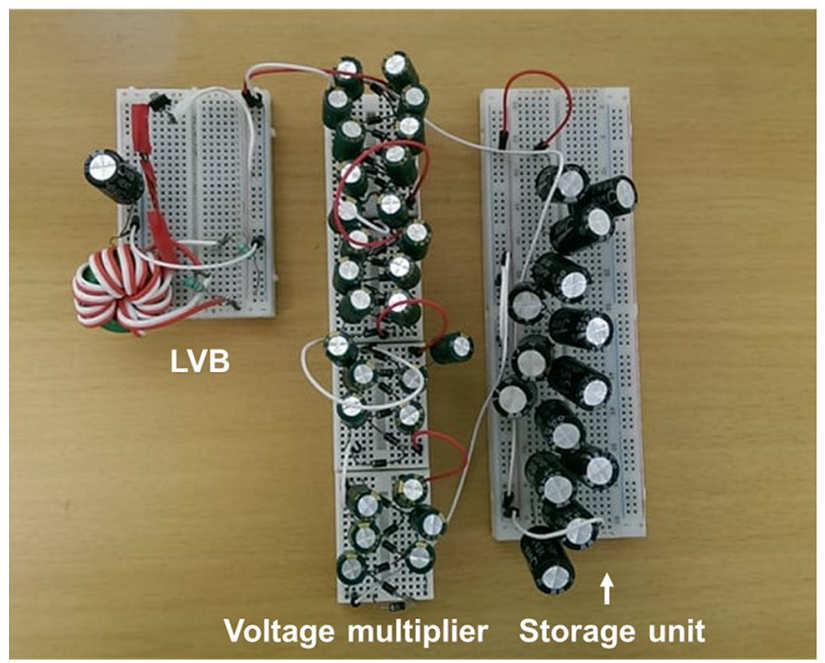

Figure 1. Photo of the newly designed low voltage booster multiplier (LVBM) system.

The PVDF-based activated carbon air-cathodes $(10 \mathrm{~cm} \times 10 \mathrm{~cm})$ were fabricated by spreading $10 \%(\mathrm{w} / \mathrm{v})$ PVDF solution containing $26.5 \mathrm{mg} / \mathrm{cm}^{2}$ of activated carbon (Norit SX-Plus, Holland) and $8.8 \mathrm{mg} / \mathrm{cm}^{2}$ of carbon black (Vulcan XC-72, Cabot Corporation, USA) directly onto a stainless steel mesh $(1 \mathrm{~mm} \times 1 \mathrm{~mm}$, type 304, Eggs, TAIHO, Co, Japan). The air-cathode MFC was inoculated with activated sludge obtained from the Sapporo Sosei wastewater treatment plant (Sapporo, Japan) and continuously fed with the primary clarifier effluent (hereafter termed as "domestic wastewater") at hydraulic retention time (HRT) of $1.5 \mathrm{~h}$ for more than one year to achieve the stable performance ${ }^{16}$. After confirming that the power generation became stable, a newly designed low voltage booster (LVB) with different numbers of AC/DC voltage multiplier circuits was connected with the MFC to evaluate its MFC energy harvesting performance.

Low voltage booster multiplier (LVBM) electronic circuit. In this study, a LVBM system was newly developed to boost and multiply the low voltage from a single air-cathode MFC. The LVBM is composed of a self-oscillating transistor-based $\mathrm{LVB}^{16}$, a multistage AC/DC voltage multiplier circuit, and a storage unit (Fig. 1). First, the low output DC voltage of MFC was boosted to an AC voltage via a direct current to alternating current (DC/AC) voltage boost converter composed of a low voltage fast-switching NPN power transistor (STN851) ${ }^{19}$ and inductors in which energy is charged and discharged into the circuit repeatedly (Fig. 2). This repeated charge and discharge cycles of the inductors enable the transistor STN851 to turn ON and OFF the circuit at a high frequency, thus inducing a high AC voltage spike ( $>2 \mathrm{~V}$ ). In this study, the transistor STN851 was selected because of its outstanding fast-switching speed and its very low saturation voltage between collector and emitter ${ }^{19}$ as compared to other bipolar junction transistors (BJTs) or metal-oxide-semiconductor field-effect transistors (MOSFETs) commonly used as a switch ${ }^{16}$.

Second, the boosted AC voltage is multiplied and converted to a DC voltage output via a multistage half-wave Cockcroft-Walton voltage multiplier circuit, which is a multistage single-phase cascade circuit of diodes and capacitors acting as a charge pump circuit at each stage (Fig. 2C) ${ }^{17,18}$. The AC voltage is rectified to DC voltage by the diode, and the current was stored in the capacitors. Therefore, the following voltage conversion flow is given;

Low DC output voltage of MFC $\rightarrow$ AC boosted voltage $\rightarrow$ Multiply AC boosted voltage $\times \mathbf{n}$

$\rightarrow$ the boosted and multiplied AC voltage is rectified to DC voltage $\rightarrow$ the electrical energy was

stored in the capacitors.

where $\mathbf{n}$ is the number of multiplying stages. The LVBM system can work even at low input current (ca. $1 \mathrm{~mA}$ ) and voltage (ca. $0.4 \mathrm{~V}$ ) without any external energy input.

Measurements of the current I (A) and voltage (V) of the MFC were performed every 30 min using a data logger (Agilent 34970A) and recorded in a personal computer. The electrode potentials were measured against an $\mathrm{Ag} / \mathrm{AgCl}$ reference electrode ( $E_{0}=195 \mathrm{mV}$ vs. SHE, RE-1B, ALS Co, Japan).

LVBM energy efficiency. The energy efficiency $(\eta)$ of the LVBM system is defined as the ratio of the energy stored in the supercapacitor $\left(E_{C a p}\right)$ and the energy consumed $\left(E_{M F C}\right)$ when the MFC was used to charge the supercapacitor (Eq. (1)) as previously described ${ }^{2,14,15}$.

$$
\eta=\frac{E_{C a p}}{E_{M F C}}
$$

where $E_{C a p}$ is the energy stored when the supercapacitor of capacitance C (Farad) was charged from $0 \mathrm{~V}$ to $\mathrm{V}$ Volt and is calculated as follows: 
(A)

(B)

(C)

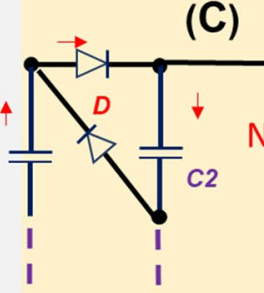

$\rightarrow$

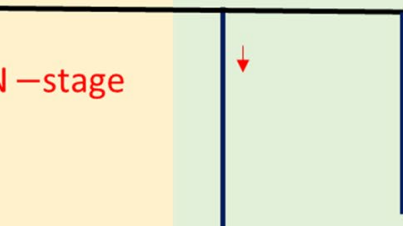

(D)

$(+)$

Final boosted and multiplied DC voltage

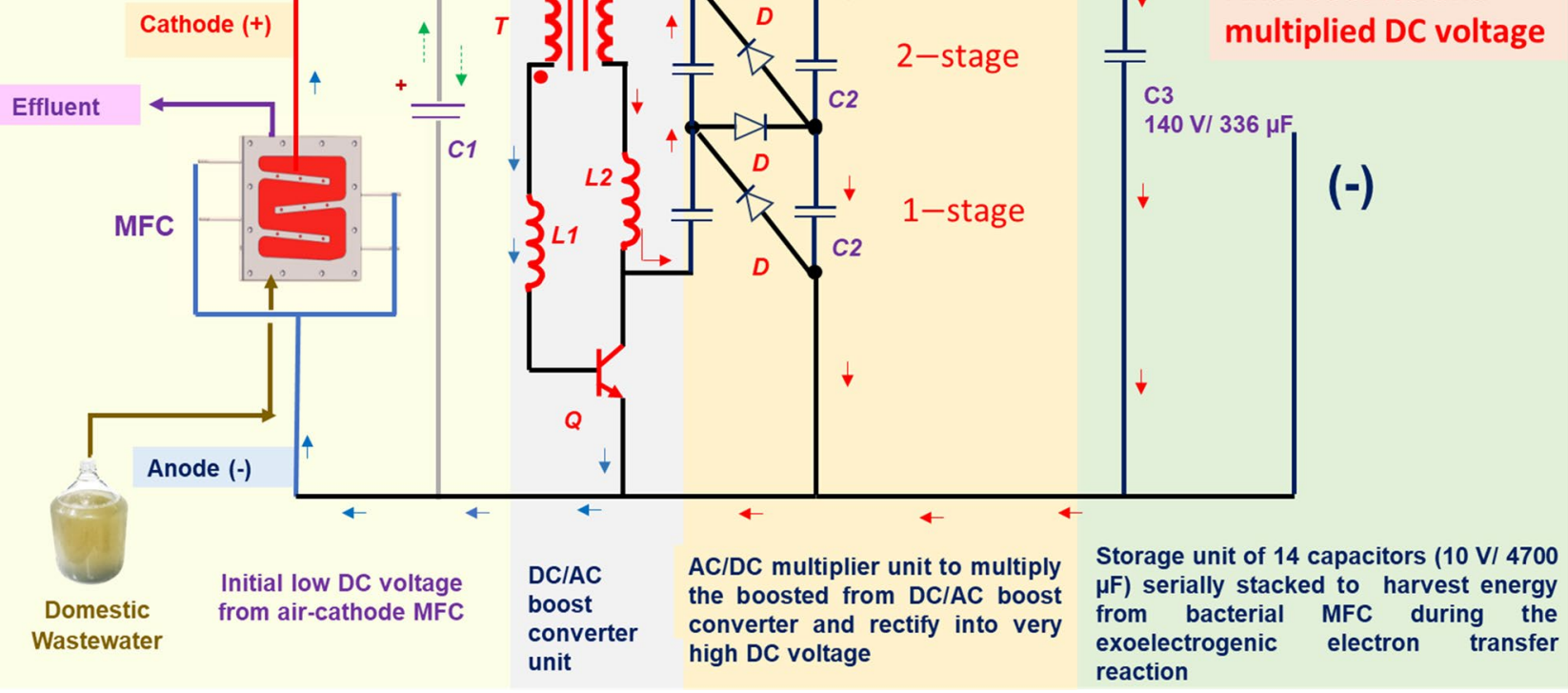

Figure 2. Diagram of the newly designed low voltage booster multiplier (LVBM) system connected to a single air-cathode microbial fuel cell (MFC) fed with domestic wastewater as substrate. (A) Air-cathode MFC fed with domestic wastewater, the brown and violet arrows indicate the influent and effluent, respectively. (C1) is a polarized capacitor $(10 \mathrm{~V} / 4700 \mu \mathrm{F})$. (B) Self-oscillating low voltage booster electronic circuit connected to the air-cathode MFC, $\mathbf{T}$ is a toroid ferrite coil inductor with double windings of 20 Turns, (L1 and L2) are axial inductors $(680 \mu \mathrm{H}), \mathbf{Q}$ is a superfast switch NPN transistor (STN851). (C) Half wave Cockcroft-Walton voltage multiplier circuit, $\mathbf{C} 2$ is a polarized capacitor $(6 \mathrm{~V} / 1500 \mu \mathrm{F}), \mathbf{D}$ is a diode rectifier $1 \mathrm{~N} 4001$. (D) Storage unit circuit, C3 is an equivalent capacitor of 10 polarized capacitors $(10 \mathrm{~V} / 4700 \mu \mathrm{F})$ serially stacked. The blue arrows represent the current flow when $\mathbf{Q}$ is $\mathrm{ON}$, and the red arrows represent the current flow when $\mathbf{Q}$ is OFF. The green dotted arrows represent the charge and discharge of capacitor $\mathbf{C 1}$.

$$
E_{\text {Cap }}=1 / 2 \mathrm{C} \times \mathrm{V}^{2}
$$

$E_{M F C}$ is calculated as the integral of the product of electrical current produced by the MFC $\left(I_{M F C}\right)$ and the MFC voltage $\left(V_{M F C}\right)$ over the supercapacitor charging time $T$ as given by Eq. $(3)^{2,15}$.

$$
E_{M F C}=\int_{0}^{\mathrm{T}} I_{M F C} V_{M F C} \mathrm{dt}
$$

To evaluate the energy harvesting efficiency, the MFC-LVBM system was used to charge five supercapacitors $(2.7 \mathrm{~V} / 350 \mathrm{~F})$ set in series. The serially stacked supercapacitors have an equivalent capacitance of $70 \mathrm{~F}$ and a total voltage of $13.5 \mathrm{~V}$. The output voltage of the array of supercapacitors, the MFC current, and the output current (current after voltage boosting) were measured every $2 \mathrm{~min}$ with the data logger. The energy efficiency test was performed in duplicate.

\section{Results and discussion}

The air-cathode MFC was continuously operated at a COD loading rate of $6.6 \pm 0.7 \mathrm{~kg} \mathrm{COD} \mathrm{m}^{-3} \mathrm{~d}^{-1}(1.5 \mathrm{~h}-\mathrm{HRT})$, and an average COD removal rate of $5.11 \pm 0.94 \mathrm{~kg} \mathrm{COD} \mathrm{m}^{-3} \mathrm{~d}^{-1}$ was achieved (Figs. S1A, S1B). The power generation fluctuated due to unstable microbial activity and the fluctuation of influent COD concentrations, and the air-cathode MFC generated the average current density of $21.48 \pm 16.97 \mathrm{~mA} \mathrm{~m}^{-3}$ and power density of $3.96 \pm 3.01 \mathrm{~W} \mathrm{~m}^{-3}$, respectively (Figs. S2A, S2B). A newly designed LVBM was connected to a single air-cathode $\mathrm{MFC}$, and its performance was evaluated. The average output voltage of the MFC during the whole experimental period was $0.45 \pm 0.03 \mathrm{~V}$. A 4-stage $\mathrm{AC} / \mathrm{DC}$ voltage multiplier circuit was connected as an extension of the LVB electronic circuit (Fig. 2A) for the initial $20 \mathrm{~h}$ (Fig. 3A). The voltage immediately increased to $17 \pm 1 \mathrm{~V}$ (Fig. 3A). Connecting an 8-stage $\mathrm{AC} / \mathrm{DC}$ voltage multiplier circuit further increased the voltage to $35 \pm 2 \mathrm{~V}$. Furthermore, 

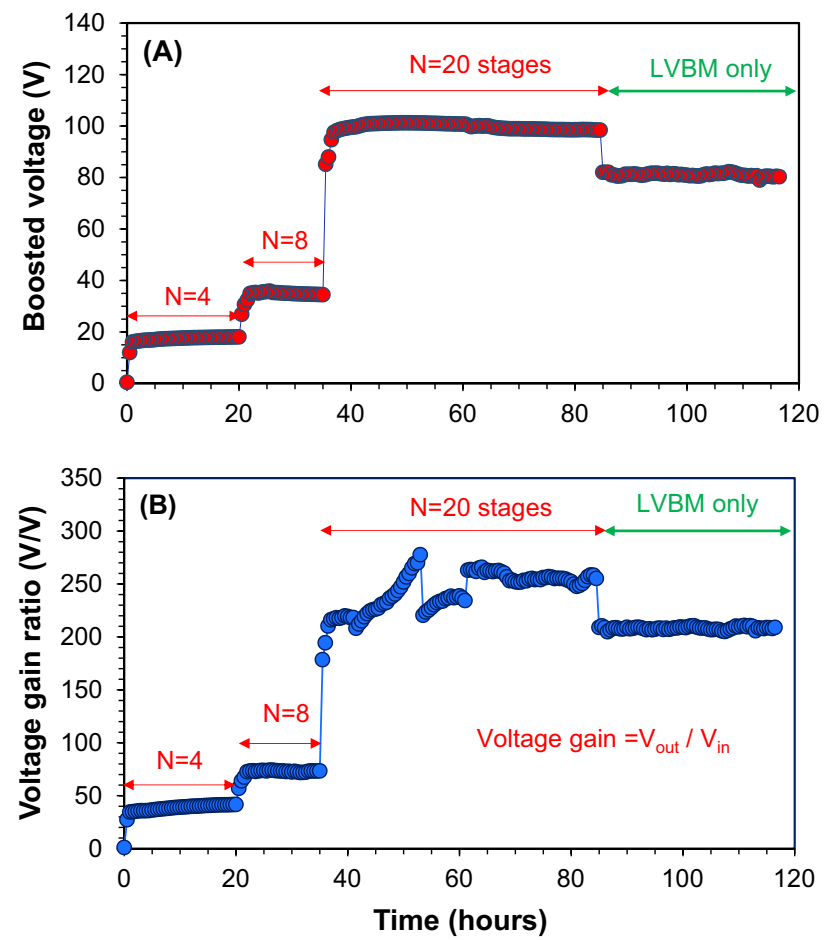

Figure 3. (A) Boosted voltage when the air-cathode MFC is connected to the LVBM with 4-stage, 8-stage, and 20 -stage multiplier circuits, respectively. (B) DC-DC voltage gain when the air-cathode MFC is connected to the LVBM system. The green arrow indicates the voltage of the LVBM when the LVBM was disconnected from the MFC.

when the number of AC/DC voltage multiplier circuit was increased to 20 stages, the boosted voltage reached $99 \pm 2 \mathrm{~V}$ (a maximum voltage was $101.24 \mathrm{~V}$ ) and was kept stably at this level for $50 \mathrm{~h}$ (Fig. 3A), which was corresponding to about 243-hold DC to DC voltage gain (Fig. 3B). The performance of the air-cathode MFC, such as the produced current, the output voltage, and the electrode potentials (vs. SHE) was very stable during the entire experimental period (Fig. 4A,B,C).

After 85-h operation, the LVBM was disconnected from the MFC, but the stable LVBM output voltage of $81 \pm 0.6 \mathrm{~V}$ was maintained for $40 \mathrm{~h}$ (Fig. 3B). This result demonstrated that since the LVBM system composed of a storage unit circuit (C3 in Fig. 2D) and serially stacked 10 polarized capacitors $(10 \mathrm{~V} / 4700 \mu \mathrm{F})$ ), it could be used to store sufficient energy to power the electronic devices when the MFC voltage source is temporarily unavailable or widely fluctuated due to unstable microbial activity and influent organic loads.

Power management systems (PMSs) for MFCs are attracting considerable attention recently. It is essential to increase the output voltage and store the power when the extracted energy is used to drive any electronic devices in practice. Various self-starting PMSs have been designed, proposed, and tested for their performance. Although some improvements have been reported, the resulting boosted voltages were able to power only lowpower electronics devices such as small wireless sensors or LEDs ${ }^{2,6,7,10,13-15,20-22}$ (Table 1). The highest boosted voltage reported to date was $12 \mathrm{~V}$, which was harvested from a benthic $\mathrm{MFC}\left(\mathrm{V}_{\mathrm{MFC}}=0.35\right.$ to $\left.0.5 \mathrm{~V}\right)$ using two in-line flyback converters ${ }^{13}$.

The newly designed LVBM in this study is based on a unique two-step approach, by which the low DC voltage of MFC is boosted to AC voltage first, the AC boosted voltage is multiplied and converted to high DC voltage, and then the multiplied high DC voltage is stored. To our best knowledge, the boosted voltage $(99 \pm 2 \mathrm{~V})$ in this study is the highest voltage that has ever been reported for a single air-cathode MFC treating low strength domestic wastewater (ca. $400 \mathrm{mg}-\mathrm{COD} \mathrm{L}^{-1}$ ) so far (Table 1). For example, Kim et al. ${ }^{6}$ applied a commercially available LTC3108 voltage booster to a single air-cathode MFC fed with diluted swine wastewater ( 2 g COD $\mathrm{L}^{-1}$ ) as substrate and obtained a boosted voltage of $3.3 \mathrm{~V}^{6}$. In addition, Park and co-workers ${ }^{14}$ used a commercially available flyback voltage booster to increase the low voltage of a single air-cathode MFC fueled with sodium acetate $\left(2 \mathrm{~g} \mathrm{~L}^{-1}\right)$ and obtained a boosted voltage of $5 \mathrm{~V}$.

Moreover, the newly designed LVBM system was found to be compatible with a low current range (7-17 mA) (Fig. 4A), which is usually produced by small lab scale MFCs. Thus, the LVBM system enabled us to boost the low MFC voltage to the required levels without voltage reversal because an only individual or parallel-connected MFCs is required to directly drive the DC/AC boost converter. In addition, since the boosted voltage is linearly correlated to the number of connected AC/DC voltage multiplier circuits (Fig. 5), we can design a LVBM which can supply the desired voltage by selecting the number of the multiplier circuit. However, the number of multiplying circuit was limited to 20 units for the safety reason in this study. Furthermore, the high voltage produced in this study is reproducible and even higher voltage $>100 \mathrm{~V}$ could be achieved if needed. The NPN transistor 

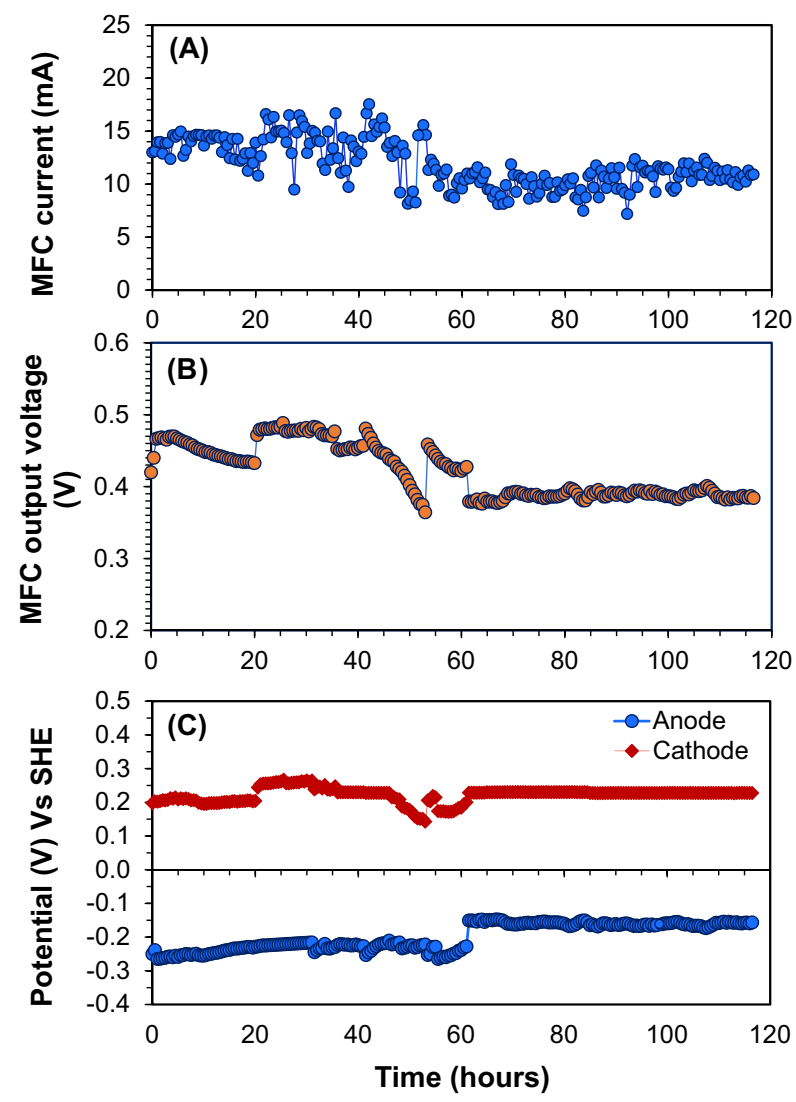

Figure 4. Time course of the produced current (A), the output voltage (B), and the electrode potentials (vs. SHE) (C) of the air-cathode MFC when the MFC was connected to the LVBM with 4-stage, 8-stage, and 20 -stage multiplier circuits, respectively.

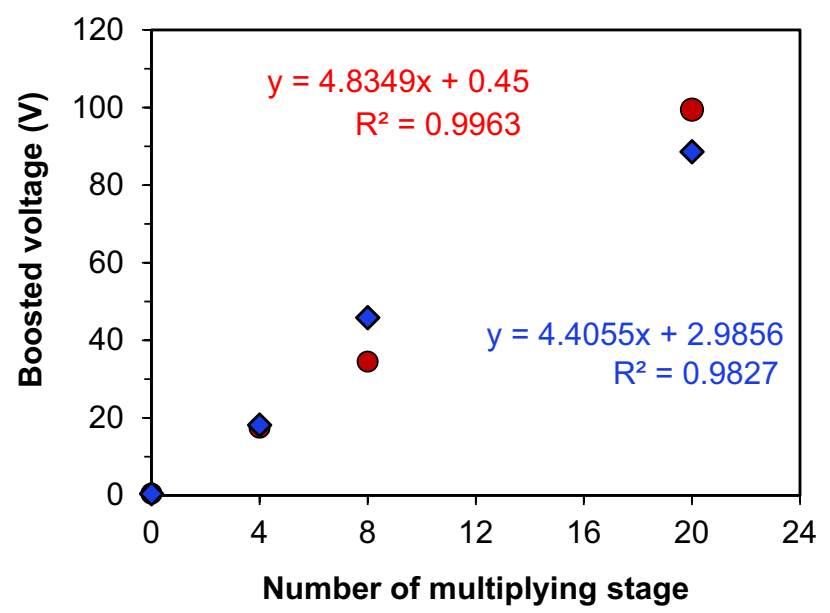

Figure 5. Correlation between the boosted voltages and the number of AC/DC voltage multiplier circuits applied. The number $n=0$ indicates the output voltage of the single-chamber air-cathode MFC. The test was conducted in duplicate. The symbol (diamond) and (circle) represent the first and second boosted voltage test, respectively, showing rebroducible results.

(STN851) used in the DC/AC boost converter can easily withstand high DC current up to $5 \mathrm{~A}$ (at $25^{\circ} \mathrm{C}$ operating temperature), which is the absolute maximum collector current rating (IC) (Table 2). This suggests that the NPN transistor-based LVBM system can be applied to a wide range of input current for large-scale practical MFC applications. For wastewater treatment application, several MFC units must be used to obtain a higher treatment capacity and power output. However, unlike conventional fuel cells, the overall power generation performance 


\begin{tabular}{|c|c|c|c|}
\hline Symbol & Parameters & Value & Unit \\
\hline $\mathrm{I}_{\mathrm{CEmax}}$ & Current collector-emitter max & 5 & A \\
\hline $\mathrm{I}_{\mathrm{Bmax}}$ & Maximum base current & 1 & A \\
\hline $\mathrm{V}_{\mathrm{CE} \max }$ & Maximum voltage collector-emitter & 60 & $\mathrm{~V}$ \\
\hline $\mathrm{I}_{\mathrm{EET}, \mathrm{MFC}}$ & Bacterial extracellular electron transfer (EET) range tested in this study to drive the LVBM system & $0.8-17$ & $\mathrm{~mA}$ \\
\hline $\mathrm{V}_{\mathrm{MFC}}$ & MFC voltage operating range tested with the MFC & $0.2-0.4$ & $\mathrm{~V}$ \\
\hline $\mathrm{V}_{\text {LVBM }}$ & Voltage LVBM range obtained & $17-102$ & $\mathrm{~V}$ \\
\hline $\mathrm{V}_{\mathrm{LVBM}} / \mathrm{V}_{\mathrm{MFC}}$ & DC-DC voltage gain & Up to 240 & $\mathrm{~V} / \mathrm{V}$ \\
\hline Temperature & LVBM operating temperature range & $15-25$ & ${ }^{\circ} \mathrm{C}$ \\
\hline $\mathrm{R}_{\mathrm{LVB}}$ & Internal resistance of the LVB system only & $91 \pm 0$ & $\Omega$ \\
\hline $\mathrm{R}_{\mathrm{M}}$ & Internal resistance of the voltage multiplier unit & N/A & $\Omega$ \\
\hline
\end{tabular}

Table 2. Operating electrical characteristics of the LVBM system used in this study. $\mathrm{I}_{\text {CEmax }}$ is the theoretical maximum current supported by the LVBM system in case of large-scale application (i.e., an array of MFCs in parallel), $\mathrm{V}_{\mathrm{CE} \text { max }}$ is the maximum voltage supported by the LVBM. N/A: Not available.

of stacked MFCs was not stable due to unstable or uneven microbial activity, which is generally limited by the worst performing unit(s). One of the solutions could be first to connect each MFC unit with a LVBM to increase or stabilize the individual power level and then connect all MFC-LVBM units in series or parallel. In this study, the MFC voltage was successfully boosted and amplified, but the current was still considerably low. In order to obtain enough power (i.e., current) to drive electronic devices, the MFC-LVBM must be connected in parallel. The feasibility study must be conducted in the future.

In this study, the LVBM was designed to harvest energy from low power generated by a single-chamber MFC without additional energy input to start. The energy harvesting efficiency of the LVBM was a key parameter to evaluate its performance and therefore evaluated using a 70-Farads $13.5 \mathrm{~V}$ supercapacitor and a single air-cathode MFC as a power supply (Fig. S4). In this experiment, the LVBM with a 4-stage AC/DC voltage multiplier circuit (LVBM-4) was used because the LVBM-4 could boost the voltage to $17 \pm 1 \mathrm{~V}$ (Fig. 5), which is close to the nominal voltage of the supercapacitor.

The LVBM-4 charged the supercapacitor to $9.3 \mathrm{~V}$ in $103.5 \mathrm{~h}$ (Fig. 6A). The output voltage of the air-cathode MFC and the current flowing from the MFC to LVBM-4 remained unchanged $\left(\mathrm{V}_{\mathrm{MFC}}=0.66 \pm 0.03 \mathrm{~V}\right.$ with $14.7 \pm 0.6 \mathrm{~mA}$, respectively) while the supercapacitor was being charged. The output current of the LVBM- 4 drastically decreased from $14.7 \pm 0.6 \mathrm{~mA}$ to $2.1 \pm 0.5 \mathrm{~mA}$ (Fig. 6B). This indicates that the LVBM- 4 charged the supercapacitor while receiving the input power of $9.82 \pm 0.54 \mathrm{~mW}$ from the MFC. Accordingly, the energy harvesting efficiency of the LVBM-4 was calculated to $82.2 \%$ (Table S1). The energy harvesting efficiency was also determined while receiving relatively low input power of $0.25 \pm 0.14 \mathrm{~mW}\left(\mathrm{~V}_{\mathrm{MFC}}=0.27 \pm 0.08 \mathrm{~V}\right.$ with $\left.0.9 \pm 0.21 \mathrm{~mA}\right)$ from the same air-cathode MFC. The LVBM- 4 could harvest $83 \%$ of the MFC energy even when the input power is low (Table S1). This result suggests that the LVBM-4 can efficiently extract and store the relatively low energy from MFCs regardless of the input power.

The energy harvesting efficiency of LVBM-4 was higher than the previously reported values of capacitorbased DC-DC converters $(5.33 \%)^{2}$, diode-based boost-converters $(22 \%)^{12}$, and flyback converters $(26-77 \%)^{13,14}$ (Table 1). This demonstrates that the LVBM has a highly efficient capacitor-charging performance. However, since the LVBM-4 extracted excessive current, the output current of the LVBM- 4 was significantly reduced to $2.1 \pm 0.5 \mathrm{~mA}$ (Fig. 6B).

Normalized energy recovery $\left(\mathrm{NER}_{\mathrm{COD}}\right)$ was proposed to evaluate the treatment performance in terms of COD removal and energy recovery ${ }^{23,24}$ (Table S2). The highest $\mathrm{NER}_{\mathrm{COD}}$ in this study was $0.148 \pm 0.007 \mathrm{kWh} / \mathrm{kg}$ COD, which is in agreement with the previously reported $\mathrm{NER}_{\mathrm{COD}}$ values for MFCs fed with domestic wastewater as fuel $^{24,25}$. The theoretical energy content in domestic wastewater was reported to be $3.86 \mathrm{kWh} / \mathrm{kg}$ COD in domestic wastewater ${ }^{25}$. Accordingly, the percentage of electrical energy recovered from real domestic wastewater is $3.83 \%$ $(0.148 / 3.86 \times 100(\%))$ in this study. Furthermore, considering that the the energy harvesting efficiency of the LVBM- 4 was $83 \%$, the MFC-LVBM system retrieved $3.2 \%$ of the theoretically available energy in wastewater in this study.

The energy harvesting efficiencies could not be determined using the LVBM-8 and LVBM-10 (8 and 10 multiplying stages) because when the boosted voltage increased, the output current became extremely low (under the detection limit of the data logger). This suggests that increasing the output voltage with the LVBM is a trade-off between current reduction and overall power (energy) loss. The number of applied multiplying stages is highly dependent on the input power ${ }^{17}$ and thus must be optimized for individual MFCs to minimize the energy loss during the energy harvesting operation. The LVBM equipped with a number of multiplying stages could be applied for pilot-scale MFCs and MECs such as a biocathode MEC $\left(1.5 \mathrm{~m}^{3}\right)$ treating municipal wastewater that continuously generated a stable power output of $406 \pm 30 \mathrm{~mW} \mathrm{~m}^{-326}$. Possible applications of the LVBM system must be explored in the future.

In summary, a low voltage booster multiplier (LVBM) was newly designed for a single air-cathode MFC, and its performance was tested. The LVBM system was able to increase the low MFC output voltage $(0.45 \pm 0.03 \mathrm{~V})$ to $99 \pm 2 \mathrm{~V}$ and hold at this voltage level for $50 \mathrm{~h}$ without voltage reversal, which was more than 243 -fold DC to DC voltage gain. The developed LVBM system was compatible with the low voltage and capable of handling widely fluctuated low current $(0.8--17 \mathrm{~mA})$ generated from low strength domestic wastewater. In addition, the LVBM 

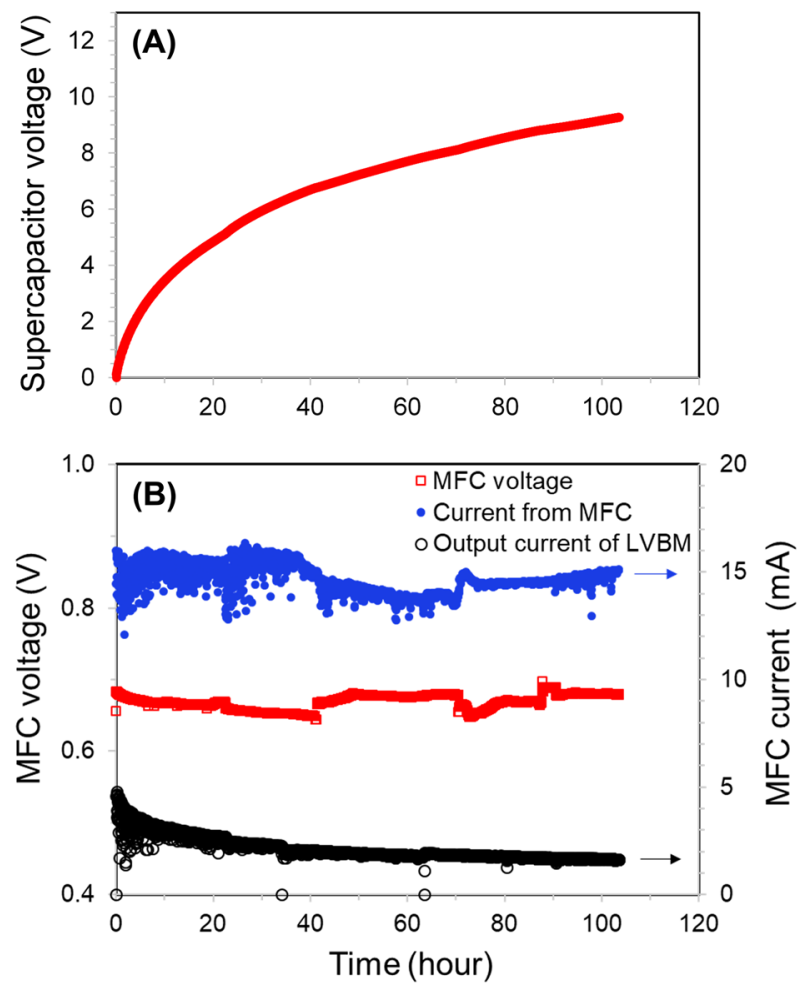

Figure 6. (A) Charging 70-F supercapacitor from $0 \mathrm{~V}$ to $9.3 \mathrm{~V}$ using a single-chamber air-cathode $\mathrm{MFC}$ as a power source with the LVBM. (B) Time course of current and voltage generated by the air-cathode MFC to power the LVBM system. The output current corresponds to the measured current after boosting the voltage with the LVBM system. MFC voltage is the output voltage when the air-cathode MFC is connected to the LVBM system to charge the supercapacitor.

output voltage was kept at $81 \pm 0.6 \mathrm{~V}$ for $40 \mathrm{~h}$ even when disconnected from the MFC, indicating that the LVBM could be used as energy storage. The energy harvesting efficiency of the LVBM was $>82 \%$. Since the LVBM is relatively cheap (less than \$10) and easily assembled, the newly developed LVBM system is implementable as a self-starting low voltage booster or efficient energy harvester for MFCs.

Received: 15 June 2020; Accepted: 20 October 2020

Published online: 04 November 2020

\section{References}

1. Torres, C. I. et al. A kinetic perspective on extracellular electron transfer by anode-respiring bacteria. FEMS Microbiol. Rev. 34, 3-17 (2010).

2. Zhang, D., Yang, F., Shimotori, T., Wang, K.-C. \& Huang, Y. Performance evaluation of power management systems in microbial fuel cell-based energy harvesting applications for driving small electronic devices. J. Power Sources 217, 65-71 (2012).

3. Pasupuleti, S. B., Srikanth, S., Dominguez-Benetton, X., Mohan, S. V. \& Pant, D. Dual gas diffusion cathode design for microbial fuel cell (MFC): Optimizing the suitable mode of operation in terms of bioelectrochemical and bioelectro-kinetic evaluation. J. Chem. Technol. Biotechnol. 91, 624-639 (2016).

4. Wang, H., Park, J.-D. \& Ren, Z. J. Practical energy harvesting for microbial fuel cells: A review. Environ. Sci. Technol. 49, 3267-3277 (2015).

5. Choi, J. \& Ahn, Y. Continuous electricity generation in stacked air cathode microbial fuel cell treating domestic wastewater. J. Environ. Manage. 130, 146-152 (2013).

6. Kim, T. et al. Boosting voltage without electrochemical degradation using energy-harvesting circuits and power management system-coupled multiple microbial fuel cells. J. Power Sources 410-411, 171-178 (2019).

7. Kim, Y., Hatzell, M. C., Hutchinson, A. J. \& Logan, B. E. Capturing power at higher voltages from arrays of microbial fuel cells without voltage reversal. Energy Environ. Sci. 4, 4662-4667 (2011).

8. Papaharalabos, G. et al. Autonomous energy harvesting and prevention of cell reversal in MFC stacks. J. Electrochem. Soc. 164, H3047-H3051 (2017).

9. Wang, H., Park, J.-D. \& Ren, Z. Active energy harvesting from microbial fuel cells at the maximum power point without using resistors. Environ. Sci. Technol. 46, 5247-5252 (2012).

10. Garita-Meza, M. A., Ramírez-Balderas, L. A., Contreras-Bustos, R., Chávez-Ramírez, A. U. \& Cercado, B. Blocking oscillator-based electronic circuit to harvest and boost the voltage produced by a compost-based microbial fuel cell stack. Sustain. Energy Technol. Assess. 29, 164-170 (2018).

11. Alipanahi, R., Rahimnejad, M. \& Najafpour, G. Improvement of sediment microbial fuel cell performances by design and application of power management systems. Int. J. Hydrog. Energy https://doi.org/10.1016/j.ijhydene.2019.04.162 (2019). 
12. Alaraj, M., Ren, Z. J. \& Park, J.-D. Microbial fuel cell energy harvesting using synchronous flyback converter. J. Power Sources 247, 636-642 (2014).

13. Babauta, J. T. et al. Scaling up benthic microbial fuel cells using flyback converters. J. Power Sources 395, 98-105 (2018).

14. Park, J.-D. \& Lee, S. Single-transistor sub-1-V self-startup voltage boost energy harvesting system for microbial fuel cells. J. Power Sources 418, 90-97 (2019).

15. Yamashita, T., Hayashi, T., Iwasaki, H., Awatsu, M. \& Yokoyama, H. Ultra-low-power energy harvester for microbial fuel cells and its application to environmental sensing and long-range wireless data transmission. J. Power Sources 430, 1-11 (2019).

16. Koffi, N. J. \& Okabe, S. Domestic wastewater treatment and energy harvesting by serpentine up-flow MFCs equipped with PVDFbased activated carbon air-cathodes and a low voltage booster. Chem. Eng. J. 380, 122443 (2020).

17. Kuffel, E., Zaengl, W. S. \& Kuffel, J. High Voltage Engineering: Fundamentals. (Butterworth-Heinemann, Oxford, 2000).

18. Wadhwa, C. L. High Voltage Engineering. (New Age International (P) Ltd., Publishers, New Delhi, 2007).

19. Low voltage fast-switching NPN power transistor. 10.

20. Wu, P. K., Biffinger, J. C., Fitzgerald, L. A. \& Ringeisen, B. R. A low power DC/DC booster circuit designed for microbial fuel cells. Process Biochem. 47, 1620-1626 (2012).

21. Ewing, T. et al. Scale-up of sediment microbial fuel cells. J. Power Sources 272, 311-319 (2014).

22. Yang, F., Zhang, D., Shimotori, T., Wang, K.-C. \& Huang, Y. Study of transformer-based power management system and its performance optimization for microbial fuel cells. J. Power Sources 205, 86-92 (2012).

23. Xiao, L., Ge, Z., Kelly, P., Zhang, F. \& He, Z. Evaluation of normalized energy recovery (NER) in microbial fuel cells affected by reactor dimensions and substrates. Bioresour. Technol. 157, 77-83 (2014).

24. Ge, Z., Li, J., Xiao, L., Tong, Y. \& He, Z. Recovery of electrical energy in microbial fuel cells: Brief review. Environ. Sci. Technol. Lett. 1, 137-141 (2014).

25. McCarty, P. L., Bae, J. \& Kim, J. Domestic wastewater treatment as a net energy producer-can this be achieved?. Environ. Sci. Technol. 45, 7100-7106 (2011).

26. He, W. et al. Field tests of cubic-meter scale microbial electrochemical system in a municipal wastewater treatment plant. Water Res. 155, 372-380 (2019).

\section{Acknowledgements}

This research was partly supported by JSPS KAKENHI (Grant Number 19H0077609 and 19H0558290), which was granted to Satoshi Okabe. N'Dah Joel Koffi was supported by the Ministry of Education, Culture, Sports, Science and Technology (MEXT), Government of Japan.

\section{Author contributions}

N.K. and S.O. designed the study, wrote the main manuscript text, and prepared all Figures and Tables. N.K. conducted the experiments. All authors reviewed the manuscript.

\section{Competing interests}

The authors declare no competing interests.

\section{Additional information}

Supplementary information is available for this paper at https://doi.org/10.1038/s41598-020-75916-7.

Correspondence and requests for materials should be addressed to S.O.

Reprints and permissions information is available at www.nature.com/reprints.

Publisher's note Springer Nature remains neutral with regard to jurisdictional claims in published maps and institutional affiliations.

Open Access This article is licensed under a Creative Commons Attribution 4.0 International License, which permits use, sharing, adaptation, distribution and reproduction in any medium or format, as long as you give appropriate credit to the original author(s) and the source, provide a link to the Creative Commons licence, and indicate if changes were made. The images or other third party material in this article are included in the article's Creative Commons licence, unless indicated otherwise in a credit line to the material. If material is not included in the article's Creative Commons licence and your intended use is not permitted by statutory regulation or exceeds the permitted use, you will need to obtain permission directly from the copyright holder. To view a copy of this licence, visit http://creativecommons.org/licenses/by/4.0/.

(C) The Author(s) 2020 